\title{
Hotel Service Recovery and Service Quality: Influences of Corporate Image and Generational Differences in the Relationship between Customer Satisfaction and Loyalty.
}

\author{
Cheng Boon Liat, Shaheen Mansori, Gan Chin Chuan \& Brian C. Imrie
}

\begin{abstract}
As the number of tourists continues to grow globally, the hospitality industry players inevitably face more challenges. High competition among the competitors and emergence of new technologies such as online booking platforms make the competition more intense among players in the hospitality sector. The quality of services provided is undoubtedly crucial to the success of the hotel. Hence any service failure has to be addressed appropriately in order to maintain a high level of customer satisfaction and to keep the image of the hotel intact. It is therefore vital that service recovery programmes are carefully planned to meet various types of service failures which may inevitably occur. In this study, questionnaires were distributed to customers who had experienced service failures. The aim was to investigate the influence of service quality and service recovery on satisfaction, and ultimately the effect on customer loyalty. The research also tested the mediating effect of corporate image between the relationship of customer satisfaction and customer loyalty. The findings showed that both service recovery and service quality had a significant impact on customer satisfaction. Similarly, it was found that customer satisfaction induced customer loyalty towards the hotel operator. The result also showed corporate image mediated partially between the relationship of customer satisfaction and customer loyalty.
\end{abstract}

Keywords: Service Recovery, Service Quality, Satisfaction, Loyalty, Corporate Image.

\section{Introduction}

Tourism plays a crucial role in contributing to the development of a nation's economy. In 2015 , the inter-national tourism receipts grew to US $\$ 1,260$ billion, an increase of $4.4 \%$ from 2014 (UNWTO, 2016). Over the decades, the tourism industry has experienced continued expansion and is a leading profit earner in the service sectors of the world economy. Due to the competitive nature of this industry, every country is striving to capture the tourism market by offering better tourism products and services. In addition, the revolutionary changes in this industry, such as the emergence of low-fare airlines and online accommo-dation booking platforms, have made travelling more affordable and convenient. Overall, it is anticipated that the rate of international tourism will grow between $3.5 \%$ and $4.5 \%$ by the end of 2016 (UNWTO, 2016). Consequently, the revenues from tourism will increase considerably.

As a major player in the tourism sector, the hos-pitality industry contributes greatly to the success of tourism in a country. As a result, providing high-quality service and managing service failures have become major concerns for hotel operators. In the hospitality industry, service failures do inevitably occur. Empirical research shows that the ability to handle a problem effectively is essential in maintaining a reputation of service excellence for many kinds of industries (Johnston \& Fern, 1999). Hence, the hotelier needs to have in place an effective service recovery pro-gram. Service recovery refers to the actions a provider takes when responding to a service failure (Gronroos, 1988). Anyone who has experienced a service failure will know the importance of service recovery in pre-venting the company's image from being tarnished. The service provider should acknowledge the problem and offer a speedy resolution to the problem when possible. However, to what extent service recovery can.

In addition, the competitive nature of marketplace and rapid expansion of hospitality industry has forced many of the businesses to differentiate themselves from other market players via 
"corporate image". This is because corporate image is regarded as an important factor in the overall evaluation of a firm. Although the relationship between customer satisfactions has been found to have direct effect on customer loyalty, Kandampully and Hu (2007) found that corporate image was also found to have a mediating effect on the relationship between customer satisfaction and customer loyalty. This scenario shows that corporate image plays a part in creating loyalty among the customers. However, the importance of corporate image is still limited in the hotel industry particularly South East Asia. Based on the discussion above, this research embarks on several objectives. Firstly, to examine the influence of service recovery and service quality on customer satisfaction. Secondly, to investigate the interrelationship between customer satisfaction, customer loyalty and corporate image. Lastly, to determine mediating and moderating effect of corporate image and different generation on the relationship in between customer satisfaction and customer loyalty.

\section{Literature Review}

In a highly competitive industry like the hotel industry, the hotelier should have an effective service recovery plan to handle any service failure promptly. One definition of service failure is the inability to meet the expectations of customers regarding the standard of service delivery (Ahmad, 2002; Mueller, Palmer, Mack, \& McMullan, 2003). Service failure, as defined by Hoffman and Bateson (2001), occurs when the actual service provided is not what is anticipated by the customer. From the customer's viewpoint, service failure occurs when something goes wrong during the process of service being rendered (Mueller et al., 2003). Hence, every service provider, especially in the hotel industry, should have a plan to execute a proper service recovery system in order to minimize customer dissatisfaction. Service recovery in this paper refers to "the actions of a service provider to mitigate and/or repair the damage to a customer that results from the provider's failure to deliver a service a designed" (Johnston \& Hewa, 1997, p. 476).

Hotel guests form their own perceptions of the hotelier following a service failure that they experience (Abbasi, Khalid, Azam, \& Riaz, 2010; Shahin \& Dabestani, 2010). The hotelier should try to return customers to a state of satisfaction (Boshor \& Staude, 2003). Griffin and Lowenstein (2002) and Evans (2002) also stressed the importance of implementing a 'winback' programme to retain valuable clients. For example, it was reported that customers who are engaged on 'win-back' programme can contribute 1.7 times more sales and sales gain of 3.4 times the average revenue for a particular business (Bowen \& Chen, 2001). Therefore, service recovery is so vital to the success of the organization that it should be incorporated in the organizational culture. An effective service recovery programme will retain customer satisfaction and ultimately profitability of the organization in the long run.

Putting in place an effective service recovery programme is essential to the service provider as it will enhance customer satisfaction and strengthen loyalty to the company (Duygun, 2015; Fornell \& Wernerfelt, 1987; Kaura, 2013; Mansori, Tyng, \& Ismail, 2014; Tax \& Brown, 1998). According to Zemke (1999), a customer who has experienced a service failure that is not followed by an appropriate response by the management will spread the word around. Hence simply by word of mouth, the company's image will be tarnished. Since each customer has needs that are different from others, it is important that a dynamic approach be adopted in the service recovery process. The hotelier needs to establish appropriate contingency procedures to handle dissatisfied customers (Liu, Warden, Lee, \& Huang, 2001). Smith, Bolton, and Wagner (1999) were of the view that the service failure and recovery experience by the customer will impact the perception of the customer towards the 
organisation. Hence, customer satisfaction can be explained as a unit of a customer's perception of the hotel delivery performance (Cheng, Mansori, \& Cham, 2014).

In line with past research, a successful service recovery would increase the level of customer satisfaction (S. Baron, Harris, Elliott, Reynolds, \& Harris, 2005; Mansori, Tyng, et al., 2014). The service provider needs to eliminate not only the cause of the customer's dissatisfaction, but also to handle the irate customer tactfully (Lewis \& Spyrakopoulos, 2001). In their effort to identify shortcomings, hoteliers usually welcome feedback on the quality of their services so that they could improve on specific areas. Researchers have proposed SERVQUAL model to measure service performance of a provider. SERVQUAL can be used to assess the quality of services offered by businesses. This model has met with heavy criticism. However, it is still widely cited in services marketing. Relationships between service quality and customer satisfaction are well accepted in service literature (e.g. Athanassopoulos, Gounaris, \& Stathakopoulos, 2001; Duygun, 2015; Gautam, 2013; Mansori, Vaz, \& Ismail, 2014; Parasuraman, Zeithaml, \& Berry, 1988; Vaz \& Mansori, 2013) However, such relationships have not been fully examined in the service recovery context.

Managing hotel service quality includes ensuring that actual service performance matches with the customer's perceived service so that customer satisfaction is achieved. However, this poses a real challenge as the quality of the relationship between service quality and customer perception towards a company is not easily established. From the perspective of services marketing, service quality is reflected at each stage of service encounter, and it is an achievement in service. In other words, it is an assessment of how well a delivered hotel service meets guest's expectations (Cheng et al., 2014). Owing to the high level of customer contact in the industry, hotel operators often evaluate the quality of services offered to the guests in order to quickly identify service failures that could leads to dissatisfaction. More importantly, each hotel operator should have a thought-out and planned process in response to service failure, in order to turn a dissatisfied customer into a satisfied customer (Fitzsimmons \& Fitzsimmons, 2013).

In the service industry, there will always be situations when service failures inevitably occur. In any case, the hotelier is obliged to respond to any such service disruption. Appropriate measures taken in response to a service failure should be part of the hotel's strategies in order to remain competitive. According to Michel, Bowen, and Johnston (2009), such a response may raise the level of customer satisfaction or reduce the degree of disappointment of the affected customers.

H1: Perceived service recovery has a significant positive influence on customer satisfaction. $\mathrm{H} 2$ : Perceived service quality has a significant positive influence on customer satisfaction.

Customers who are satisfied with the services provided by the hotel are very likely to be satisfied with the services experienced, which in turn will create loyalty among them (Kandampully \& Hu, 2007). According to Kumar and Shah (2004), only by strengthening customer loyalty can hotels be profitable. As the cost of attracting new customers is higher than retaining existing ones, therefore hotels should do all that is necessary to strengthen customer loyalty. Customer loyalty is defined as an assurance that a customer will select the same product or service of a certain brand repeatedly although there may be many similar offers by rival companies (Oliver, 1999). Hence, a satisfied customer is very likely to be a loyal customer. On the other hand, the customer who has experienced an unresolved service failure will most probably not repeat their stay at the same hotel.

H3: Customer satisfaction has a significant positive influence on customer loyalty. 
Howe and Strauss (2009) suggested that evolvement of macro-environment affects the profile of people who are born in a certain era which also possess similar purchasing and consumption behaviour. Individuals who are born between 1977 and 2000 are usually defined as the Y or Millennial generation (Bakewell \& Mitchell, 2003; Mansori, Cheng, \& Shan, 2012; Noble, Haytko, \& Phillips, 2009; Wolburg \& Pokrywczynski, 2001). This generation is labelled as having low levels of brand loyalty, is techno savvy, self-centred, environmentallyconscious, and spend more, which has different values, characteristics and behaviour compared to generation X who are born between 1961 and 1970s (Bakewell \& Mitchell, 2003; Freestone \& Mitchell, 2004). Therefore, diverse generations might perceive and behave differently such as in the situation of satisfaction and loyalty.

H4: Different generation moderate the relationship of customer satisfaction and customer loyalty.

Customer satisfaction does drive loyalty, but it is not the only factor that induces loyalty. According to Faullant, Matzler and Füller (2008) corporate image and satisfaction influences the degree of customer loyalty. Corporate image can be viewed as customers' perception on the organisation. It could be the brand and what it stands for, or the kind of associations that customers have with the organisation and the services it offers (Nguyen \& Leblanc, 2002; Simoes, Dibb, \& Fisk, 2005). In the context of hotel industry, corporate image in this paper refers to the perception of a hotel's identity in the guests' minds. Studies have shown that there is a positive correlation between corporate image and customer loyalty, and corporate image might induce customer loyalty (Faullant et al., 2008; Han, Hsu, \& Lee, 2009; Kandampully \& Hu, 2007). Much research has been done in establishing corporate image in influencing customer perceptions and their behaviour. However, there is minimal research focusing on its mediating effect between customer satisfaction and loyalty within the hotel industry. Faullant et al., (2008) in their research showed that corporate image and customer satisfaction play a crucial role in encouraging loyalty among customers. They believe that such a model would help to understand the relationship in between corporate image and customer loyalty.

H5: Corporate image mediates between the relationship of customer satisfaction and customer loyalty.

Based on above evidence and to provide empirical evidence for the inter-relationships among service quality, service recovery, customer satisfaction, loyalty, corporate image and generation, especially with regard to the hotel industry, the hypotheses for the present study were postulated.

The proposed conceptual model was developed as shown below:

\section{Insert Figure 1 here}

\section{Research Methodology}

In the present study, self-administered questionnaire was used and distributed to 500 tourists from Malaysia and other countries. In order to ensure that all outcomes were given equal chance of getting selected, a non-probability purposive sampling approach was used for the purpose of this study. The target respondents were approached by researchers at the waiting 
area and entry/exit point of Kuala Lumpur International Airport and Kuala Lumpur International Airport 2 while they were waiting for their flights.

In recent decades, Malaysia tourism industry has been contributing substantial revenue to the economy. In 2014, the local tourism industry had once again marked another growth, with tourism dollars amounting to RM72 billion (USD295.2 billion). This was an increase of approximately RM6.56 billion or 10\% in hard currency earnings compared to RM 65.44 billion (USD16.30 billion). In spite of intense competition and numerous challenges in the tourism industry, tourist arrivals are on the uptrend for many years (Tourism Malaysia, 2014). As shown in Table 1, the growth in tourist arrivals in Malaysia has spurred the construction of new hotels. The above facts make Malaysia as one of the good platforms for studies related to tourists' behaviour and hospitality industry.

\section{Insert table 1 here}

The participants were selected based on two criteria; first they should have an experience of staying at any 4 or 5 star hotels in Malaysia within 6 months by the date of participation and second they should encounter any sort of service failure from their perspective. After obtaining agreement from the target respondents on voluntary participation, a brief explanation of the purpose of the survey and questionnaires were distributed to them. As for ethical reason, the researchers guaranteed anonymity and confidentiality to the respondents who participated in this study. Out of the distributed questionnaires $(n=500), 442$ questionnaires were usable as the remaining were rejected due to incompleteness and were unusable.

For the context of measurement, the measurement scale for service quality (five items) was adopted from Suhartanto (2011), who measured service quality based on customers' overall perception on service experience. Moreover, service recovery items were adopted from the study by Cheng (2015). The service recovery comprised of three dimensions; distributive justice (four items), procedural justice (four items), and interactional justice (four items). As for customer satisfaction, the measurement employed in this study was adapted from the scale developed by Kuo, Chang, Cheng, and Lai (2013) and was operationalized with four items based on tourists overall satisfaction about the hotel that they had stayed. Corporate image in the present study was measured using the ten-item scale developed by Kandampully and Suhartanto (2000), which operationalized based on holistic image and image attributes. Moreover, customer loyalty in this study was based on the seven-item scale by Skogland and Siguaw (2004) which was operationalized based on customers' willingness to recommend, revisit intention, and positive word of mouth. Moreover, all other measurement items for the constructs in this study were assessed using a 5-point Likert scale, from $1=$ Strongly Disagree to $5=$ Strongly Agree. All data collected were analysed using both SPSS and AMOS statistical software.

\section{Data Analysis \\ Sample Characteristics}

The demographic profile for the respondents in the present study was presented in Table 2 with the use of descriptive statistic. According to Table 2, it was indicated that $53.6 \%$ of the respondents who participated in this study were female. In terms of age group, the majority of the respondents were aged between 26 to 35 years old (29\%). Moreover, the majority of the respondents were married $(55.4 \%)$ and were international tourists $(73.1 \%)$. As far as the 
profession was concerned, most of the respondents were working for a company $(41.2 \%)$ and business owners $(32.8 \%)$, whereby the rest were unemployed. The statistic also revealed that most of the respondents were travelling with their family members $(50.2 \%)$ and had stayed at hotels in the range of $1-3$ times $(40.5 \%)$.

\section{Insert Table 2 Here}

\section{Validity and Reliability}

Validity and reliability analyses had been run to test the suitability of the developed measurement for this study. Average Variance Extracted (AVE), Composite Reliability (CR) and Cronbach's alpha had been calculated for all constructs of this study. Hair et al. (2010) further added the recommended threshold value for the above suggestion such as: (1) factor loading for each item must exceed 0.70, (2) AVE must exceed 0.50 and (3) the reliability score must exceed 0.70 , in order for the convergent validity to establish. Based on the assessment of factor loading among the constructs, four items of the corporate image were dropped as their loadings were below the recommended value of 0.70 . After the removal of the items, Table 3 shows that all loadings for the measurement items were greater than 0.60 , the AVE for all the constructs exceeded 0.50, and the reliability score for all the constructs exceeded 0.70 , thus convergent validity was achieved.

\section{Insert Table 3 Here}

\section{Structural Model and Hypothesis Testing}

From Table 4, the estimates of the standardized coefficients indicated that the hypothesized path between each construct was positive and significant. Specifically, H1, H2, H3, were significant at 95 percent confidence level. This revealed that proper service recovery and service quality have a significant positive influence on customer satisfaction. Moreover, customer satisfaction has a significant positive influence on customer loyalty. However, the results showed that the generation gap between Gen X and Gen Y did not have a moderating role on the relationship between satisfaction and loyalty as the critical ratio for t-test was less than 1.96 .

In addition, based on the results from Table 4, in order to establish the existence of this mediation effect, there were three preliminary conditions that should be met: (1) The predictor variable (customer satisfaction) should significantly influence the mediator variable (corporate image) and the dependent variable (customer loyalty) (R. M. Baron \& Kenny, 1986). All the conditions for mediation were tested and verified in all the models presented in Table 5. Based on the findings from Sobel test, it can be concluded that corporate image partially mediated the relationship between customer satisfaction and customer loyalty.

\section{Insert Table 4 Here}

\section{Insert Table 5 Here}

\section{Discussions and Implications of Study}

The findings of the present study highlighted several important findings that worth to be noted. First, it was found that service recovery and service quality affected the level of customer satisfaction in Malaysian hotel industry positively. The findings confirmed the service marketing theory that perceptions of the overall service recovery and service quality 
that a hotel guest is accorded have a significant impact on the level of his satisfaction. Perceived as a whole by the hotel guest, the combination of service recovery (if any) and service quality comprises various services rendered, and the recovery actions taken by the management during a specific period of hotel stay (Parasuraman, Zeithaml, \& Berry, 1985; Parasuraman et al., 1988). Just as service performance quality has a significant impact on the judgment or perception of a customer; service recovery actions also influence the level of satisfaction of a customer who has experienced service failure during his stay. Service recovery also helps to generate valuable word-of-mouth advertising about the company and helps to minimize any negative market perception due to service failure. In the face of keen competition in the service industry, it is important to analyse and understand more fully the impact of service recovery on the acquisition of new customers and the retention of existing ones. The findings of this study concur with those in most previous researches on hotel service quality (e.g. Lau, Lee, \& Ho, 2005). Due to the high level of customer contact, the hospitality industry is particularly prone to service failures and perceptions of service quality (Sweeney \& Soutar, 2001). Skilled personnel in hospitality should be employed so that matters concerning customer care policy and procedures can be executed smoothly.

In addition, the importance of service improvement in the service quality dimensions, i.e. tangible, responsiveness, assurance, reliability, and empathy, should be emphasized by the hoteliers. For example, hotels should consider upgrading their exterior and interior side of the buildings in order to create positive impression among their customers. Moreover, the upgrading of the amenities like website, booking system, room facilities, etc. can be important in influencing customers' perception of the hotel. Hotel operators should emphasize on the importance of assurance aspect by ensuring the safety of the customers is well taken care of. This can be performed with the provision of appropriate training to the security officers, key card access review, control after-hours access, and maintain securityminded customer service. As the context of responsiveness, reliability and empathy, hotel operators should provide training and courses that can assist employees in improving the work performance and service delivery process. These trainings should encompass the standard of procedures at the front desk, providing prompt services, error-free customer services, and any other training modules. In addition, cultural training should also be provided to the employees as hotel institution is often patronized by customers from different countries and cultural background. By doing so, this can facilitate hotel operation and allow the services to be performed in an effective and efficient manner.

Although studies have generally found that customer satisfaction induced customer loyalty (e.g. Chitty, Ward, \& Chua, 2007; Olorunniwo, Hsu, \& Udo, 2006; Yap, Wong, Loh, \& Bak, 2010) some researchers argued that customer satisfaction does not necessarily lead to customer loyalty (Bowen \& Chen, 2001; Olsen, 2002; Skogland \& Siguaw, 2004). Despite opposing findings of customer satisfaction vis-a-vis customer loyalty, the findings of this study are in line with other researches done in hotel industry, that is, customers who are satisfied with the services rendered by the hotel will probably be loyal customers (Chitty et al., 2007; Kandampully \& Suhartanto, 2000; Olorunniwo et al., 2006). The findings confirmed the marketing theory that customer satisfaction has a positive impact on with customer loyalty. Customer loyalty is a much valued asset to an organization, especially in the hotel industry where there is a very keen competition. As the cost of successfully attracting a new customer is 6 to 15 times more costly than that of sustaining an existing one, hoteliers should adopt marketing approaches that enhance customer satisfaction. For example, the feedbacks or suggestion programs should be emphasized by most of the hotels as this method can allow them to identify any weak areas that need to improve in their 
operation. This can be performed with the use of survey forms that can be distributed either at the front desk or via email. Effective strategies would help translate customer satisfaction into customer loyalty, besides attracting prospective customers.

Studies that cast doubt about the predictability of loyalty often make use solely of customer satisfaction ratings while ignoring corporate image as a predictor of loyalty. According to Faullant et al. (2008), corporate image and overall customer satisfaction play an important role on loyalty intention. With regard to the mediating effect, this study found that corporate image partially mediated between the relationship of customer satisfaction and loyalty. Sobel's test result showed that nearly $64 \%$ of the effect of customer satisfaction on customer loyalty was attributed by corporate image while only $34 \%$ of the effect on customer loyalty was directly due to customer satisfaction. As pointed out by Kandampully and $\mathrm{Hu}$ (2007), the main determinant of customer loyalty seemed to be positive corporate image. An organization which maintains a high level of service quality and which has very satisfied customers would very likely enjoy a very positive corporate image. Such an organization would then enjoy the patronage of loyal customers and their friends who, by word-of-mouth, become new customers. Since satisfied hotel guests have a positive perception of the hotel's image, it is very likely that not only will their patronage be retained and loyalty assured, but it will also help the hotel to gain new customers. Marketing strategies for long-term growth should therefore incorporate steps to improve the hotel's corporate image. For example, consideration of the use of interactive marketing approach such as social media and word of mouth marketing can be used by the hotels to improve their brand image.

Hotel operator should stress the importance of service recovery to guarantee customer service justice. For instance, the management can offer remedial service recovery by compensating customers with a free upgrade for their rooms or free meal coupon. In the context of procedural justice, it is suggested that management should perform a procedural service recovery when there is a failure in their service delivery process. Friendly standard policies and rules must be enforced to tackle the failure by offering an apology with detail explanation to the customers and rectify the mistake immediately. This can prevent customer dissatisfaction with the particular hotels. In addition, management can improve interactional justice by offering intensive training and short courses that can develop staff knowledge and communication skills particularly in handling service failures. Having good interpersonal skills can boost the confidence of the staff as well as enhance the image of the hotel and in the process improve customer satisfaction which will subsequently lead to a higher level of customer loyalty (Cheng et al., 2014; Fitzsimmons \& Fitzsimmons, 2013). Previous research suggested that generation $\mathrm{Y}$ has been labelled as having low levels of brand loyalty as compared to generation X (Bakewell \& Mitchell, 2003; Freestone \& Mitchell, 2004). However, the finding of this study did not support the notion especially in the context of hotel service recovery. In view of that, hotel operators need to convey service uniqueness to their guest in regardless of generation. Additional effort should be channelled towards fostering positive feelings or customer satisfaction among the guest during their hotel stay.

\section{Limitations and Conclusion}

There are two limitations identified in this study. Firstly, the model developed for this study was tested in Malaysian hospitality setting. As such, the findings might not necessarily be applicable to other contexts. Secondly, the questionnaire made use only of close-ended questions to collect data for this study. Such questions did not allow for the full range of emotions to be elicited, especially with regards to encounters with service recovery 
initiatives. Close-ended questions also precluded the inclusion of valuable background narratives which would help to shed more light on the findings of the research. Hence, further research into the role of service recovery and service quality in raising the degree of customer satisfaction and loyalty in other service settings (e.g. hedonic service consumption, retail, etc.) might enhance the existing theory. Moreover, future research should also consider triangulation method in the context of research methods in order to produce more reliable findings.

This study investigated the relationship of service quality and service recovery perceptions, and their effects on customer satisfaction. The findings would be helpful to hoteliers who wish to devise more effective loyalty strategies through enhancing their corporate image. As hotel customers become more sophisticated in their demands, and also in view of intense competition in the hospitality sector, hotel service provider need to understand well available options to maintain their existing customers as well as attract new ones. As an international player in the global hotel industry, the Malaysian hotelier plays a key role in creating a memorable "home away from home" experience for foreign guests. It is vital to ensure robust growth in the local hotel industry so that it can act as a catalyst for the tourism industry, a major sector in the Malaysian Economic Transformation Programme (ETP).

\section{References}

Abbasi, A. S., Khalid, W., Azam, M., \& Riaz, A. (2010). Determinants of customer satisfaction in hotel industry of Pakistan. European Journal of Scientific Research, $8(1), 97-105$.

Ahmad, S. (2002). Service failures and customer defection: a closer look at online shopping experiences. Managing Service Quality: An International Journal, 12(1), 19-29.

Athanassopoulos, A., Gounaris, S., \& Stathakopoulos, V. (2001). Behavioural responses to customer satisfaction: an empirical study. European journal of marketing, 35(5/6), 687-707.

Bakewell, C., \& Mitchell, V.-W. (2003). Generation Y female consumer decision-making styles. International Journal of Retail \& Distribution Management, 31(2), 95-106.

Baron, R. M., \& Kenny, D. A. (1986). The moderator-mediator variable distinction in social psychological research: Conceptual, strategic, and statistical considerations. Journal of personality and social psychology, 51(6), 1173.

Baron, S., Harris, K., Elliott, D., Reynolds, K. L., \& Harris, L. C. (2005). When service failure is not service failure: an exploration of the forms and motives of "illegitimate" customer complaining. Journal of services marketing, 19(5), 321-335.

Boshor, C., \& Staude, G. (2003). Satisfaction with service recovery: Its measurement and its outcomes. South African Journal of Business Management, 34(3).

Bowen, J. T., \& Chen, S.-L. (2001). The relationship between customer loyalty and customer satisfaction. International Journal of Contemporary Hospitality Management, 13(5), 213-217.

Cheng, L. B. (2015). Perceived justice in service recovery and customer satisfaction: Evidence from the Malaysian hotel industry. International Journal of Advances in Management and Economics, 4(5), 7-13.

Cheng, L. B., Mansori, S., \& Cham, H. T. (2014). The associations between service quality, corporate image, customer satisfaction, and loyalty: Evidence from the Malaysian hotel industry. Journal of Hospitality Marketing \& Management, 23(3), 314-326. 
Chitty, B., Ward, S., \& Chua, C. (2007). An application of the ECSI model as a predictor of satisfaction and loyalty for backpacker hostels. Marketing Intelligence \& Planning, 25(6), 563-580.

Duygun, A. (2015). The impacts of customer loyalty on negative word-of-mouth communication and repurchase intention. Journal of Marketing and Management, $6(1), 16$.

Evans, M. (2002). Prevention is better than cure: Redoubling the focus on customer retention. Journal of Financial Services Marketing, 7(2), 186-198.

Faullant, R., Matzler, K., \& Füller, J. (2008). The impact of satisfaction and image on loyalty: the case of Alpine ski resorts. Managing Service Quality: An International Journal, $18(2), 163-178$.

Fitzsimmons, J., \& Fitzsimmons, M. (2013). Service management: Operations, strategy, information technology: McGraw-Hill Higher Education.

Fornell, C., \& Wernerfelt, B. (1987). Defensive marketing strategy by customer complaint management: a theoretical analysis. Journal of Marketing research, 337-346.

Freestone, O., \& Mitchell, V. (2004). Generation Y attitudes towards e-ethics and internetrelated misbehaviours. Journal of Business Ethics, 54(2), 121-128.

Gautam, V. (2013). Linkages Between Switching Barriers and Service Recovery Evaluation: An Indian Exploration. Journal of Global Marketing, 26(3), 147-154.

Griffin, J., \& Lowenstein, M. W. (2002). Customer winback: How to recapture lost customers-and Keep them loyal: John Wiley \& Sons.

Hair, J., JF, Black, W., Babin, B., Anderson, R., \& Tatham, R. (2010). Multivariate data analysis New Jersy: Pearson Education.

Han, H., Hsu, L.-T. J., \& Lee, J.-S. (2009). Empirical investigation of the roles of attitudes toward green behaviors, overall image, gender, and age in hotel customers' ecofriendly decision-making process. International Journal of Hospitality Management, 28(4), 519-528.

Hoffman, K. D., \& Bateson, J. E. (2001). Essentials of services marketing: Concepts, strategies and cases: South-Western Pub.

Howe, N., \& Strauss, W. (2009). Millennials rising: The next great generation: Vintage.

Johnston, T. C., \& Hewa, M. A. (1997). Fixing service failures. Industrial marketing management, 26(5), 467-473.

Kandampully, J., \& Hu, H.-H. (2007). Do hoteliers need to manage image to retain loyal customers? International Journal of Contemporary Hospitality Management, 19(6), 435-443.

Kandampully, J., \& Suhartanto, D. (2000). Customer loyalty in the hotel industry: the role of customer satisfaction and image. International Journal of Contemporary Hospitality Management, 12(6), 346-351.

Kaura, V. (2013). Service convenience, customer satisfaction, and customer loyalty: Study of Indian commercial banks. Journal of Global Marketing, 26(1), 18-27.

Kumar, V., \& Shah, D. (2004). Building and sustaining profitable customer loyalty for the 21st century. Journal of Retailing, 80(4), 317-329.

Kuo, N.-T., Chang, K.-C., Cheng, Y.-S., \& Lai, C.-H. (2013). How service quality affects customer loyalty in the travel agency: The effects of customer satisfaction, service recovery, and perceived value. Asia Pacific Journal of Tourism Research, 18(7), 803822.

Lau, K.-N., Lee, K.-H., \& Ho, Y. (2005). Text mining for the hotel industry. Cornell Hotel and Restaurant Administration Quarterly, 46(3), 344-362.

Lewis, B. R., \& Spyrakopoulos, S. (2001). Service failures and recovery in retail banking: the customers' perspective. International Journal of Bank Marketing, 19(1), 37-48. 
Liu, T.-C., Warden, C. A., Lee, C.-H., \& Huang, C.-T. (2001). Fatal service failures across cultures. Journal of Hospitality \& Leisure Marketing, 8(1-2), 93-111.

Mansori, S., Cheng, L. B., \& Shan, L. (2012). A Study ff E-Shopping intention in Malaysia: The influence of generation X \& Y. Australian Journal of Basic and Applied Sciences, 6(8), 28-35.

Mansori, S., Tyng, G. G., \& Ismail, Z. M. M. (2014). Service recovery, satisfaction and customers' post service behavior in the Malaysian banking sector. Management Dynamics in the Knowledge Economy, 2(1), 5-20.

Mansori, S., Vaz, A., \& Ismail, Z. (2014). Service quality, satisfaction and student loyalty in malaysian private education. Asian Social Science, 10(7), 57-66.

Michel, S., Bowen, D., \& Johnston, R. (2009). Why service recovery fails: Tensions among customer, employee, and process perspectives. Journal of Service Management, 20(3), 253-273.

Mueller, R. D., Palmer, A., Mack, R., \& McMullan, R. (2003). Service in the restaurant industry: an American and Irish comparison of service failures and recovery strategies. International Journal of Hospitality Management, 22(4), 395-418.

Nguyen, N., \& Leblanc, G. (2002). Contact personnel, physical environment and the perceived corporate image of intangible services by new clients. International Journal of Service Industry Management, 13(3), 242-262.

Noble, S. M., Haytko, D. L., \& Phillips, J. (2009). What drives college-age Generation Y consumers? Journal of business research, 62(6), 617-628.

Oliver, R. L. (1999). Whence consumer loyalty? the Journal of Marketing, 33-44.

Olorunniwo, F., Hsu, M. K., \& Udo, G. J. (2006). Service quality, customer satisfaction, and behavioral intentions in the service factory. Journal of services marketing, 20(1), 5972.

Olsen, S. O. (2002). Comparative evaluation and the relationship between quality, satisfaction, and repurchase loyalty. Journal of the Academy of Marketing Science, $30(3), 240-249$.

Parasuraman, A., Zeithaml, V. A., \& Berry, L. L. (1985). A conceptual model of service quality and its implications for future research. the Journal of Marketing, 41-50.

Parasuraman, A., Zeithaml, V. A., \& Berry, L. L. (1988). SERVQUAL: A multiple-item scale for measuring customer expectations of service. Journal of Retailing, 64(1), 1240.

Shahin, A., \& Dabestani, R. (2010). Correlation analysis of service quality gaps in a four-star hotel in Iran. International Business Research, 3(3), 40.

Simoes, C., Dibb, S., \& Fisk, R. P. (2005). Managing corporate identity: an internal perspective. Journal of the Academy of Marketing Science, 33(2), 153-168.

Skogland, I., \& Siguaw, J. A. (2004). Are your satisfied customers loyal? Cornell Hotel and Restaurant Administration Quarterly, 45(3), 221-234.

Smith, A. K., Bolton, R. N., \& Wagner, J. (1999). A model of customer satisfaction with service encounters involving failure and recovery. Journal of Marketing research, 356-372.

Sweeney, J. C., \& Soutar, G. N. (2001). Consumer perceived value: The development of a multiple item scale. Journal of Retailing, 77(2), 203-220.

Tax, S. S., \& Brown, S. W. (1998). Recovering and learning from service failure. MIT Sloan Management Review, 40(1), 75.

Vaz, A., \& Mansori, S. (2013). Malaysian private education quality: Application of SERVQUAL model. International Education Studies, 6(4), 164.

Wolburg, J. M., \& Pokrywczynski, J. (2001). A psychographic analysis of Generation Y college students. Journal of advertising research, 41(5), 33-52. 
Yap, K. B., Wong, D. H., Loh, C., \& Bak, R. (2010). Offline and online banking-where to draw the line when building trust in e-banking? International Journal of Bank Marketing, 28(1), 27-46. 
Figure 1. Conceptual Framework

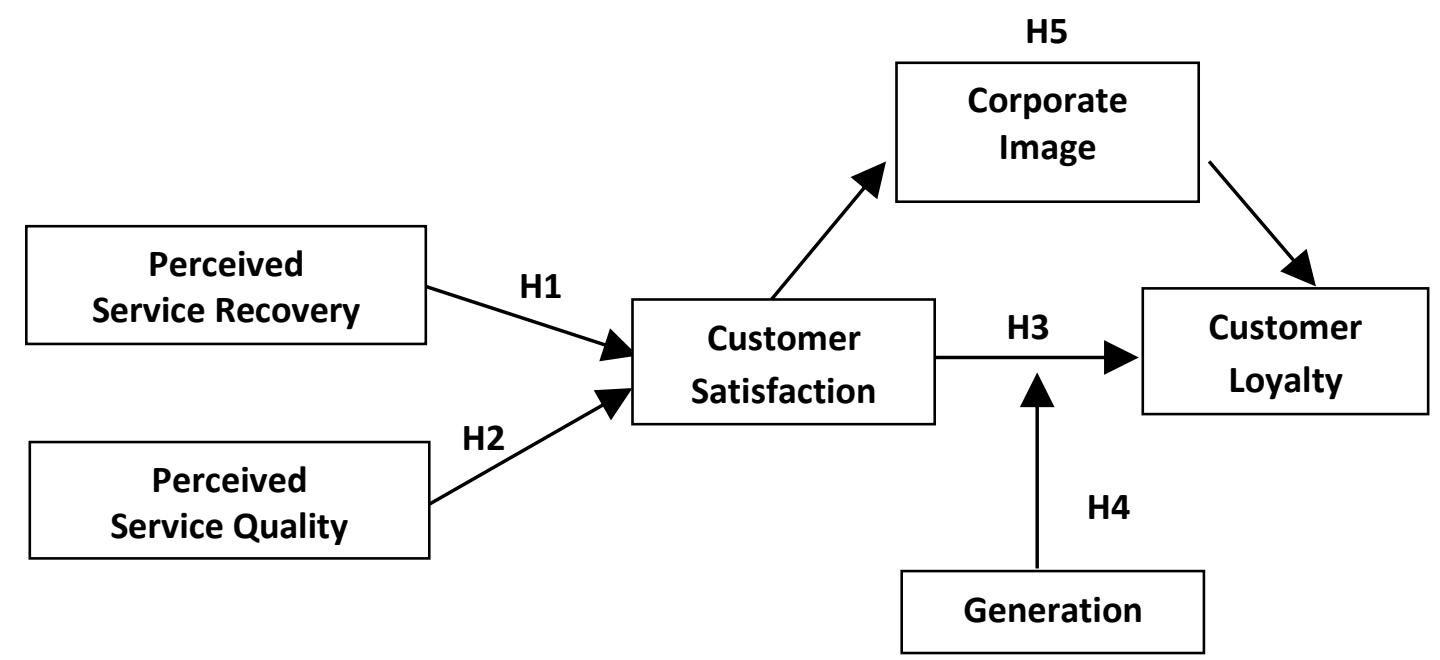

Table 1: The numbers of Registered Hotels and Rooms in Malaysia

\begin{tabular}{ccc}
\hline Year & Hotel Registered & Number of Rooms \\
\hline 2014 & 1858 & 170464 \\
\hline 2013 & 1843 & 167247 \\
\hline 2012 & 1765 & 157891
\end{tabular}

Note: The Statistic are adopted from Malaysian Hotel Association (MHA), 2014

Table 2: Demographic Profile Respondents $(n=442)$

\begin{tabular}{llcc}
\hline \multicolumn{1}{c}{ Variable } & \multicolumn{1}{c}{ Details } & Frequency & Percentage (\%) \\
\hline Gender & Male & 205 & 46.4 \\
& Female & 237 & 53.6 \\
Age & 18-25 years old & 88 & 19.9 \\
& 26-35 years old & 128 & 29.0 \\
& 36-50 years old & 86 & 19.5 \\
& 51-65 & 72 & 16.3 \\
\multirow{3}{*}{ Marital Status } & 66 and above & 68 & 15.4 \\
& Single & 192 & 43.4 \\
& Married & 245 & 55.4 \\
Nationality & Divorced & 5 & 1.1 \\
& Malaysian & 119 & 26.9 \\
& Non Malaysian & 323 & 73.1 \\
Occupation & & & \\
& Student & 40 & 9.0
\end{tabular}




\begin{tabular}{llcc} 
& Working for company & 182 & 41.2 \\
& Owner of a business & 145 & 32.8 \\
& Retired & 57 & 12.9 \\
\multirow{5}{*}{ Travel Category } & Others & 18 & 4.1 \\
& Single Traveller & 78 & 17.6 \\
& Family & 222 & 50.2 \\
\multirow{5}{*}{ Travelling } & Business & 81 & 18.3 \\
Frequency & Others & 61 & 13.8 \\
& 1 to 3 & 179 & 40.5 \\
& 4 to 5 & 137 & 31.0 \\
& More than 5 times & 126 & 28.5 \\
\hline
\end{tabular}

Table 3: Test Results on Convergent Validity and Discriminant Validity

\begin{tabular}{lllll}
\hline & CR & FL & AVE & Cronbach's Alpha \\
\hline Distributive Justice & 0.885 & $0.780-0.833$ & 0.659 & 0.88 \\
Procedural Justice & 0.833 & $0.711-0.786$ & 0.555 & 0.83 \\
Interactional Justice & 0.847 & $0.739-0.783$ & 0.581 & 0.84 \\
Service Recovery & 0.918 & - & 0.52 & 0.90 \\
$\quad$ second order) & & & & \\
Service Quality & 0.907 & $0.625-0.811$ & 0.660 & 0.90 \\
Customer Satisfaction & 0.829 & $0.719-0.769$ & 0.548 & 0.83 \\
Corporate Image & 0.892 & $0.680-0.801$ & 0.541 & 0.89 \\
Customer Loyalty & 0.887 & $0.654-0.779$ & 0.511 & 0.88 \\
\hline
\end{tabular}

Notes: $C R=$ Composite Reliability; $F L=$ Factor Loading; $A V E=$ Average Variance

Extracted.

Table 4: Results of Hypotheses Testing

\begin{tabular}{llll}
\hline Hypothesized Path & S.R.W $\boldsymbol{\beta}$ & Critical Ratio & $\begin{array}{l}\text { Supported } \\
(\text { Yes/No) }\end{array}$ \\
\hline $\begin{array}{l}\text { H1: Service Recovery } \rightarrow \text { Customer } \\
\text { Satisfaction }\end{array}$ & 0.683 & $14.77^{*}$ & Yes \\
$\begin{array}{l}\text { H2: Service Quality } \rightarrow \text { Customer Satisfaction } \\
\text { H3: Customer Satisfaction } \rightarrow \text { Customer }\end{array}$ & 0.1 & $2.843^{*}$ & Yes \\
$\begin{array}{l}\text { Loyalty } \\
\text { H4: Moderation Role of Generation }\end{array}$ & 0.560 & $10.498^{*}$ & Yes \\
$\begin{array}{l}\text { Customer Satisfaction } \rightarrow \text { Customer Loyalty } \\
\text { Gen Y }\end{array}$ & & & \\
\hline
\end{tabular}




\begin{tabular}{llll}
\hline Gen X & 0.559 & $13.81^{*}$ & Yes \\
& & Critical & Supported \\
& p-value & Ratio & (Yes/No) \\
t-test & 0.648 & 0.457 & No \\
\hline
\end{tabular}

Notes: *p-value <0.05; S.R.W= Standardized Regression Weight.

Table 5: SEM results for Mediation Effect of Corporate Image

\begin{tabular}{lccc}
\hline \multicolumn{1}{c}{ Path } & S.R. W $\boldsymbol{\beta}$ & Critical Ratio & $\begin{array}{c}\text { Supported } \\
\text { (Yes/No) }\end{array}$ \\
\hline Customer Satisfaction $\rightarrow$ Corporate Image & $0.258^{*}$ & 4.767 & Yes \\
Customer Satisfaction $\rightarrow$ Customer Loyalty & $0.550^{*}$ & 11.688 & Yes \\
Corporate Image $\rightarrow$ Customer Loyalty & $0.172^{*}$ & 3.730 & Yes \\
Sobel Test & p-value & Critical Ratio & Supported \\
Mediation role of Corporate Image on & & & (Yes/No) \\
Customer Satisfaction $\rightarrow$ Customer Loyalty & & & Yes \\
\hline
\end{tabular}

Notes: *p-value $<0.05$ 